\title{
Nucleolar localization of the ErbB3 receptor as a new target in glioblastoma
}

\author{
Marzia Tagliaferro ${ }^{1 \dagger}$, Paolo Rosa ${ }^{1 \dagger}$, Gian Carlo Bellenchi ${ }^{2,3,4}$, Daniela Bastianelli ${ }^{5}$, Rosa Trotta ${ }^{6,7}$, Claudia Tito $^{8}$, \\ Francesco Fazi ${ }^{8}$, Antonella Calogero ${ }^{1,5}$ and Donatella Ponti ${ }^{1,6^{*}}$
}

\begin{abstract}
Background: The nucleolus is a subnuclear, non-membrane bound domain that is the hub of ribosome biogenesis and a critical regulator of cell homeostasis. Rapid growth and division of cells in tumors are correlated with intensive nucleolar metabolism as a response to oncogenic factors overexpression. Several members of the Epidermal Growth Factor Receptor (EGFR) family, have been identified in the nucleus and nucleolus of many cancer cells, but their function in these compartments remains unexplored.

Results: We focused our research on the nucleolar function that a specific member of EGFR family, the ErbB3 receptor, plays in glioblastoma, a tumor without effective therapies. Here, Neuregulin 1 mediated proliferative stimuli, promotes ErbB3 relocalization from the nucleolus to the cytoplasm and increases pre-rRNA synthesis. Instead ErbB3 silencing or nucleolar stress reduce cell proliferation and affect cell cycle progression.

Conclusions: These data point to the existence of an ErbB3-mediated non canonical pathway that glioblastoma cells use to control ribosomes synthesis and cell proliferation. These results highlight the potential role for the nucleolar ErbB3 receptor, as a new target in glioblastoma.
\end{abstract}

Keywords: ErbB3, Neuregulin, Nucleolus, UBF, Nucleolin, Glioblastoma, Actinomycin D

\section{Background}

In the eukaryotic cells the production of ribosomes takes place in the nucleolus, a specialized subnuclear compartment where the RNA Polymerase I (RNA Pol I) catalyses the ribosomal RNA synthesis (rRNA). The activity of this enzyme is under the control of two main factors, UBF and SL1 both components of the complex that stabilizes RNA Pol I on rDNA promoter [1, 2]. Ribosomal RNA is synthesised as precursor $47 \mathrm{~S}$ pre-rRNA which is subjected to specific and highly regulated processing steps that allow to mature $18 \mathrm{~S}, 5.6 \mathrm{~S}$ and $28 \mathrm{~S}$ RNAs. During ribosomal RNA

\footnotetext{
*Correspondence: donatella.ponti@uniroma1.it

${ }^{\dagger}$ Marzia Tagliaferro and Paolo Rosa contributed equally to this work.

${ }^{6}$ Laboratory of Tumor Inflammation and Angiogenesis, Center for Cancer

Biology (CCB), VIB, Leuven, Belgium

Full list of author information is available at the end of the article
}

processing, ribosomal proteins are incorporated into the pre-ribosomal subunits to form the mature $40 \mathrm{~S}$ and $60 \mathrm{~S}$ subunits. Tumor suppressors, oncogenes and alternatively deregulated upstream signalling pathways can directly influence the RNA polymerase I activity inducing hyper activation of rRNA transcription in cancer cells. Thus, the control of ribosome assembly and protein synthesis is essential for the survival of cancer cells. Tumor suppressors such as retinoblastoma (pRB) and p53 negatively regulate RNA polymerase I and interfere with the assembly of transcriptional machinery on the rDNA promoter. In this context, during any sort of stress condition the alternative reading frame protein p14ARF subtracts MDM2, an E3 ubiquitin ligase, from the interaction with p53 in manner to free and stabilise p53 level in the nucleolus of the cell where it inhibits RNA polymerase I activity [3]. Recently we demonstrated the involvement of EGR1, 
an early gene normally induced after stress signal, as negative regulator of RNA polymerase I [4]. Nucleolar function of EGR1 is strictly linked to the expression of nucleolar proteins such as nucleophosmin (B23) and alternative reading frame (p14ARF). These findings demonstrated the action of a new specific nucleolar network EGR1-B23-ARF, alternative to p53, that negatively regulates RNA polymerase I in cancer cells [5]. Nucleolar activity is also influenced by the interaction between pathways activated from extracellular signals in order to coordinate ribosome synthesis and cell proliferation [6]. Indeed, proteomic analysis has shown that a variety of proteins involved in ribosome biogenesis and proteins that have extra nucleolar function with effects on cell cycle and apoptosis localize in the nucleolus [7-11] are chromatin modulators and transcriptional regulators that influence nucleolar activity [12]. The EGFR/ERBB/HER proto-oncogene family consists of four type-I tyrosine kinase receptors, ErbB1-4 and many studies indicate, the presence in the nucleus and nucleolus of several ErbB receptors [13-15]. Generally, these receptors explain their function on the cell membrane where, after the binding with growth factors or neuregulin undergo to homo or hetero oligomerization with the activation of the intrinsic tyrosine kinase activity and the subsequent recruitment of proteins involved in the cytoplasmic signalling pathways. This signalling generates crosstalks with multiple cellular processes such as proliferation, cell mobility and apoptosis [14]. Since the EGFR signalling promotes proliferation in tumor the EGFR receptors often represent a marker of resistance with poor prognosis. All EGFR family members have been described in the nuclei of various normal and/or tumoral cell lines, either as full length receptors either as alternatively generated nuclear variants or as proteolytically cleaved proteins. While ErbB1 and ErbB2 were identified in the nucleus as full-length molecules/ proteins [15-17], ErbB4 and ErbB3 were found in the nucleus as truncated isoforms. In particular a shorter $80 \mathrm{kDa}$ ErbB3 variant regulates the expression of cyclin D1 and relocalizes in the nucleolus of H358 cells after p14ARF over expression [13, 18]. Our hypothesis is that several of these EGFR receptors, could directly influence the nuclear and/or nucleolar activity in cancer cells. Particularly we focused our attention on the nucleolar function of ErbB3 receptor in glioblastoma. ErbB3 is a $180-\mathrm{kDa}$ transmembrane glycoprotein composed of three regions, a NH2-terminal extracellular ligand-binding region, a transmembrane domain, and an intracellular region containing the $\mathrm{COOH}$-terminal [19]. It is expressed in normal brain preferentially as full length although recently it has been identified also as truncated isoforms of $55 \mathrm{kDa}$ and $21 \mathrm{kDa}$ which presumably include only the C-terminal domain [20].

The first hypothesis was that ErbB3 could be subjected to stepwise proteolysis. However the absence of metalloproteinase proteins' cleavage sites has suggested that the nuclear protein could be the result of an alternative splicing [21].

Primary ligands of ErbB3 are the members of the neuregulin (NRG) family. After NRG activation, the ErbB3 receptor physically associate with other ErbB family members, to form heterodimers or higher-order oligomers [22].

The presence of ErbB3 in the nucleolus has been described in several cancer cell lines but its function in this compartment remains unexplored at moment. We further explored the ErbB3 nucleolar function in glioblastoma describing, for the first time, the presence of the $50 \mathrm{kDa}$ variant of ErbB3 receptor in the nucleolus of glioblastoma cells. Under neuregulin stimulation it relocalizes to the cytoplasm with a concomitant increasing of the 47S pre-rRNA synthesis. The impairment of ErbB3 trafficking by silencing or promoting nucleolar stress, determines a cell cycle block and affects cell survival. This nuclear/cytoplasm traffic of ErbB3 observed in vitro was also confirmed in ex-vivo in glioblastoma primary cells. Our findings support the hypothesis for the existence, of an ErbB3 alternative pathway controlling cell proliferation of glioblastoma cells that opens new perspectives to investigate therapeutic approaches aimed to modulate ErbB3 in glioblastoma.

\section{Results}

\section{Nuclear-cytoplasmic localization of ErbB3 receptor}

Glioblastoma is a common adult brain tumor in which the enhanced malignant potential correlates with the expression of ErbB1 [14, 15]. Although there is an extensive literature concerning the role of ErbB1 in glioblastoma, few studies have investigated the contribution to glioblastoma development by the other members of the ErbB family, such as ErbB3. In tumors ErbB3 localizes in the nucleus and is often over expressed when cells escape from the antiproliferative effects of ErbB1 inhibitors, thus suggesting its possible involvement in resistance development. Little is known regarding the role of ErbB3 in the nucleus. To address this point we investigate ErbB3 localization by immunostaining with anti ErbB3 (named SC-285) antibody, that recognise specifically the $\mathrm{C}$-terminal region of the receptor. Immunostainings were performed in different glioblastoma cell lines such as the U-87MG, known to express ErbB3, the U-251MG and the U-373MG (Fig. 1A). We also observed a strong signal in HeLa, a uterine cervix cancer cell line characterised by the 

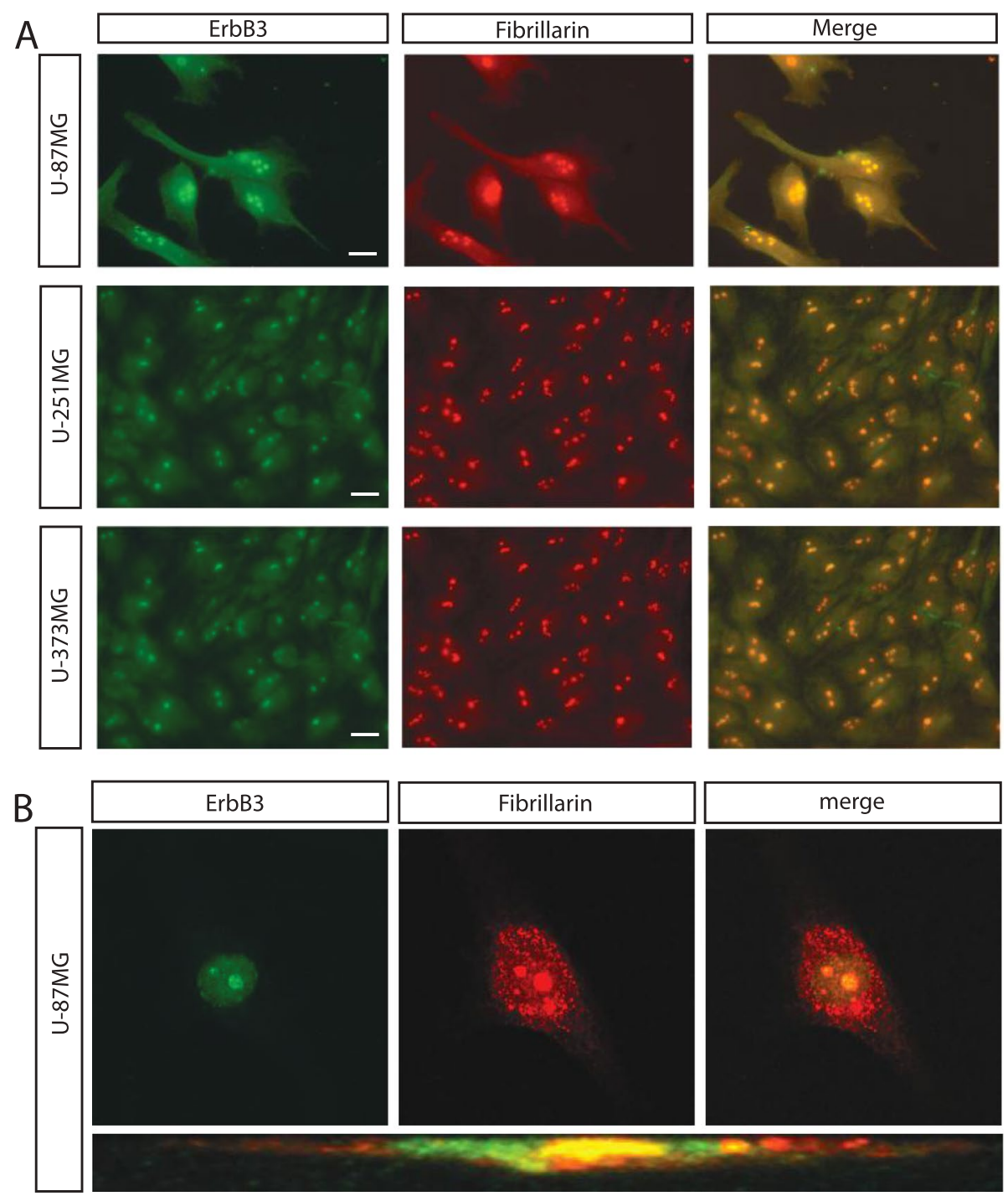

Fig. 1 ErbB3 localizes in the nucleolus of ovarian and glioblastoma cell lines. Immunofluorescence analysis for ErbB3 (green) and Fibrillarin (red) after $24 \mathrm{~h}$ of serum starvation (0.2\% FBS), in the glioblastoma cell lines U-87MG, U-251MG and U-373MG (A). Confocal magnifications and relative lateral sections are shown for U-87MG cells (B). ErbB3 staining was performed by using rabbit polyclonal anti-ErbB3 sc-285. The colocalization is shown in yellow. Scalebar represent $10 \mu \mathrm{m}$

absence of ErbB3 receptor on the cell surface [23] and in MCF-7 known to express ErbB3 on the plasma membrane [24] (Fig. S1). We found that ErbB3 colocalizes with the nucleolar markers fibrillarin or the RNA polymerase I subunit RPA40 in all the glioblastoma cell lines analysed although with different intensity of the signal while in MCF-7 ErbB3 appears expressed on the cell surface and in both the nucleus and in the nucleoli of the cells. The ErbB3 nucleolar localization was further confirmed by confocal imaging using conventional and lateral resolution for U-87MG and HeLa cells (Fig. 1B and Fig. S1).
As expected any nucleolar staining was detected when the immunofluorescence was performed in absence of primary antibody and without permeabilization (Fig. S2A,B). U-87MG cells were also stained for ErbB3 by using a different source of antibody (named RTJ2). The nucleolar staining and the colocalization with fibrillarin was confirmed also in this case (Fig. S3).

Since NRG1 has a crucial role in ErbB3 activation [25] we investigate if and how it may control ErbB3 nucleolar localization. To this purpose U-87MG cells were stimulated with NRG1 $\left(15^{\prime}\right)$ and then analysed for ErbB3 expression. We found that NRG1 treatment 


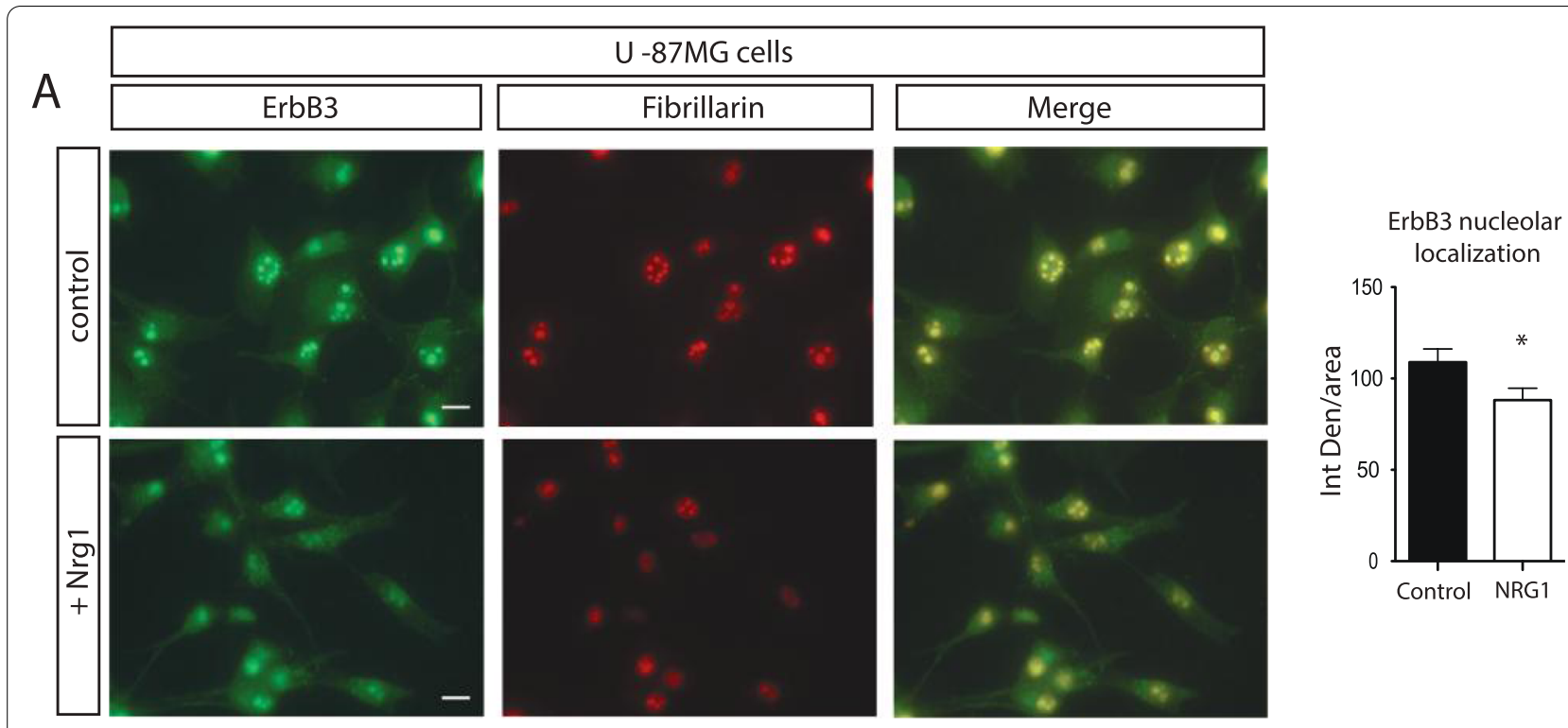

B

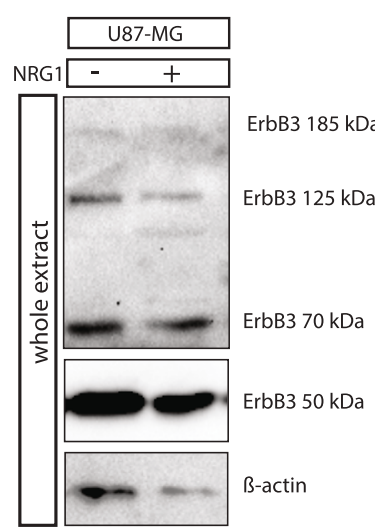

C

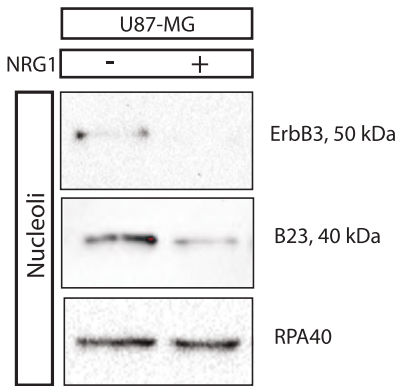

D

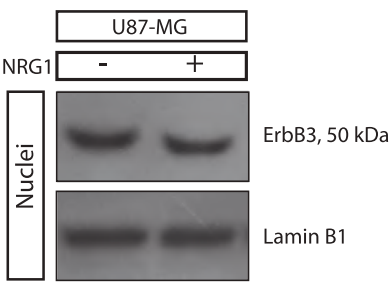

$\mathrm{E}$
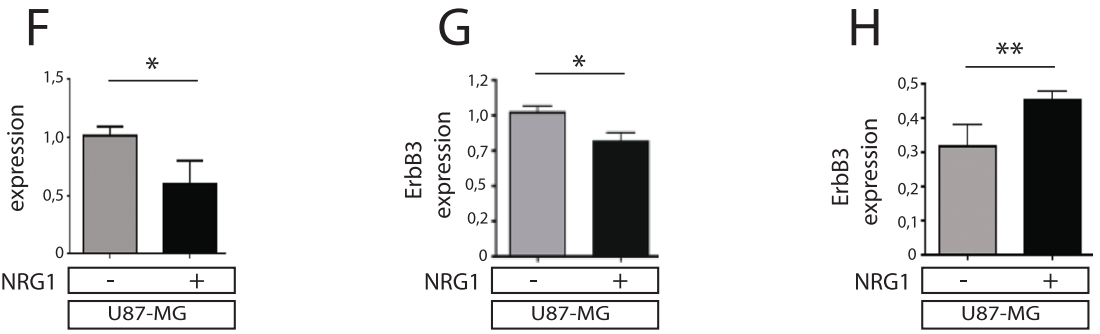

Fig. 2 Nucleolar localization of ErbB3 is under the control of Neuregulin1. Immunofluorescence analysis for the ErbB3 receptor (green) and B23 (red) in U-87MG cells before and after Neuregulin1 treatment (A). The colocalization is shown in yellow. Scalebar represent $10 \mu \mathrm{m}$. Densitometric quantification of the ErbB3 signal in the nucleoli was performed by Image J. U-87MG cell lines were subjected to cell fractionation after 15 min of Neuregulin1 stimulation and analysed by western blot. Whole extract (B), purified nucleoli (C), Nucleoplasm (D) and cytoplasmic extracts (E) were probes with anti ErbB3, anti B23 (only for nucleoli) and specific antibodies for each compartments corresponding to anti Pol I subunit RPA40 for the nucleoli; anti GAPDH for the cytoplasm and anti lamin B1 for the nuclei. The proteins amount loaded in each lane were: whole extract $80 \mu \mathrm{g}$, nucleoli, $4 \mu \mathrm{g}$; nuclei $10 \mu \mathrm{g}$; cytoplasm $40 \mu \mathrm{g}$. The quantification data shown in $\mathrm{F}-\mathrm{H}$ are the average of three independent experiments and significant results are highlighted with asterisks $\left({ }^{*} p<0.05,{ }^{* *} p<0.01\right)$

induces a significant reduction of nucleolar ErbB3 in U-87MG (Fig. 2A). The nucleolar marker nucleophosmin (B23) was also reduced. To investigate if the reduction in the immunofluorescence signal after proliferative stimuli was effectively associated to a reduced expression of nucleolar ErbB3, we analysed the expression of the protein in whole extract, nucleoplasm, cytoplasm and nucleoli after cell fractionation 
in U87-MG cell lines (Fig. 2B-E). In all samples the prevalent form of ErbB3 corresponded to the short $50 \mathrm{kDa}$ variant, although in whole lysate weaker signals, for the ErbB3 fragments at $125 \mathrm{kDa}$ and $70 \mathrm{kDa}$, were visible. The full length ErbB3 receptor of $185 \mathrm{kDa}$ appeared instead always as a faint band (Fig. 2B). The short $50 \mathrm{kDa}$ ErbB3 variant was also the predominant form in MCF-7 cells (S4). The nucleolar expression of the $50 \mathrm{kDa}$ ErbB3 receptor was strongly reduced after NRG1 treatment (Fig. 2C,F), while its levels in the nucleus (Fig. 2C,G) and in the cytoplasm (Fig. 2D,H) were slightly but significantly changed, after NRG1 treatment. A similar trend was observed in HeLa cells were we found up to a 20\% average reduction of ErbB3 after NRG1 stimulation in the nucleolus of this cells (Fig. S5A-F), thus confirming the immunofluorescence data. These findings suggest that NRG1 drives the shuttling of the $50 \mathrm{kDa}$ ErbB3 variant from the nucleolus to the cytoplasm both in U87-MG and HeLa cells.

\section{ErbB3 interacts with nucleolar proteins}

The nucleolus is a subnuclear compartment devoted to ribosomes biogenesis. Ribosome synthesis requires $80 \%$ of cell energy. For this reason this process is tightly regulated via extracellular and intracellular signalling that in the nucleolus control the synthesis of the $47 \mathrm{~S}$ pre-rRNA through the modulation of the RNA polymerase I activity $[1,2]$. Since all the proteins that localize in this structure are somehow linked to ribosome biogenesis, we investigated the involvement of ErbB3 in this process by analysing through qPCR the levels of $47 \mathrm{~S}$ pre-rRNA. Interestingly the reduction of nucleolar ErbB3 expression correlates with an increased expression of the $47 \mathrm{~S}$ ribosomal precursor in both HeLa and U-87MG cell lines (Fig. 3A). Thus we hypothesised that ErbB3 could regulate RNA Polymerase I by modulating the Upstream Binding Factor (UBF) activity, a key component controlling the transcription of $47 \mathrm{~S}$ pre-rRNA. To address this hypothesis we searched for a possible interaction

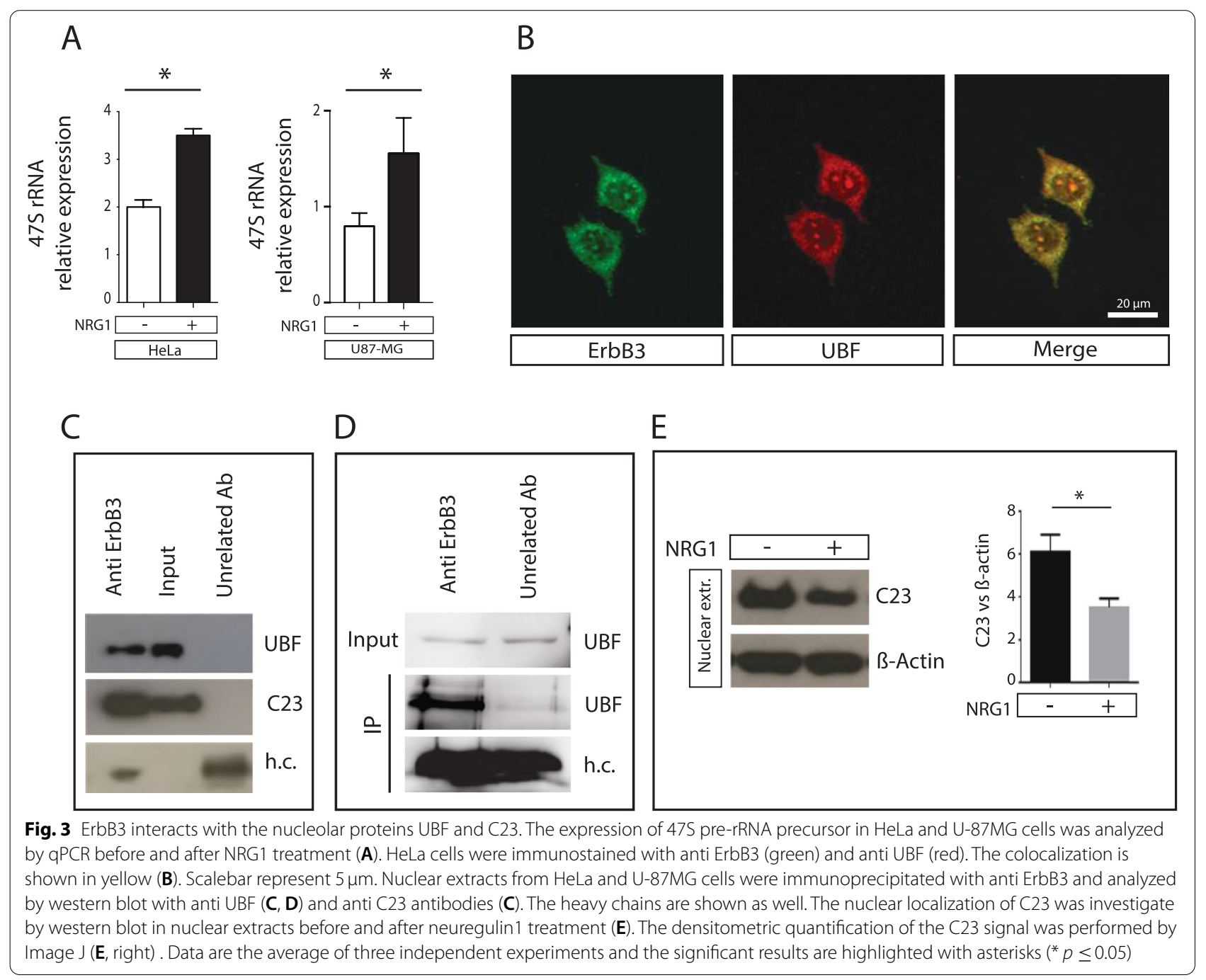


between ErbB3 and UBF through experiments of immunocolocalization and immunoprecipitaton. To this purpose we used HeLa cells since they have higher number of nucleoli if compared to other cell lines and represent a good model to dissect nucleolar interactions. Here ErbB3 colocalizes in the nucleolus with UBF (Fig. 3B) in absence of NRG1 stimulation. When we immunoprecipitated the ErbB3 complex with an anti ErbB3 antibody we found an enrichment also in UBF, while no enrichment was detected when we used an unrelated antibody either in HeLa either in U-87MG (Fig. 3 C,D). Since other members of EGFR family (ErbB1 and ErbB2) interact with the nucleolar protein nucleolin (also known as C23) [26, 27], we investigate and confirmed that $\mathrm{C} 23$ is also part of the ErbB3-UBF complex (Fig. 3C). These data suggest that ErbB3 is interested in multiple interactions in the nucleolus. Since C23 is a nucleolar protein involved in ribosomal precursor processing and shuttles from the nucleolus to the cell membrane $[26,27]$ under proliferation stimuli, we verify if it undergoes shuttling upon NRG1 stimulation. To this purpose we profiled its expression in nuclear extracts. After NRG1 treatment the C23 protein level decreases in the nucleus (Fig. 3E) as described for ErbB3.

\section{ErbB3 and nucleolar stress}

Nucleolar metabolism is strictly linked to the rate of cell proliferation, besides cancer cells have a higher number of the nucleoli when compared to non-pathological cells [3]. In additionthe size of the nucleoli is proportional to the rate of ribosomes biosynthesis and any stressful condition such as that obtained by a chemotherapy agent causes reduction of ribosome biogenesis and decreases their size.

To investigate the involvement of $50 \mathrm{kDa}$ ErbB3 in the nucleolar metabolism we used Actinomycin D, a molecule that at low dose induces nucleolar stress [28]. HeLa and U-87MG cell lines were both treated with Actinomycin $\mathrm{D}$ for $1 \mathrm{~h}$ and the nuclear extracts, once purified, were analysed by western blot. A significant increasing of the short variant ErbB3 was detected in the nucleoplasm of both cell lines after treatment (Fig. 4A-C). Under nucleolar stress also $\mathrm{C} 23$ accumulates in the nucleus, suggesting a possible functional link between these proteins (Fig. 4A-F). To investigate if the interference on ErbB3 nuclear-cytoplasmic traffic has effect on cell viability we measured cell viability by trypan blue assay in U-87MG cells after Actinomycin D low dose treatment for $24 \mathrm{~h}$ and $72 \mathrm{~h}$. We observed a clear effect on cell viability with increased cell death from 1.4 to 4 folds respectively at $24 \mathrm{~h}$ and $72 \mathrm{~h}$ (Fig. 4G-H). Furthermore, Actinomycin D induced changes in the growth medium $\mathrm{pH}$ as a result of a lower metabolic activity induced by nucleolar stress (Fig. S6).
ErbB3 silencing affects survival of glioblastoma cell line To better understand the role of ErbB3 in the nucleolus we knocked down ErbB3 by silencing its expression through specific siErbB3 that targets the exon 2 of the $E r b B 3$ gene. To this purpose $30 \mathrm{nM}$ of siErbB3 was used to obtain a significant reduction of both mRNA and protein in U-87MG cells (Fig. 5A-C). ErbB3 silencing elicited an average reduction of $30-60 \%$ protein levels, if compared with a scramble siRNAs (Fig. 5C). In addition ErbB3 silencing resulted in a significant reduction of cell cycle at $\mathrm{S}$ phase $(11 \%)$ when compared to si-Scramble (21\%) (Fig. 5D) and in the reduction of cell viability of 1,6 folds and 3,3 folds at $24 \mathrm{~h}$ and $72 \mathrm{~h}$ respectively if compared to control samples (Fig. 5E,F). This data supports our hypothesis that the ErbB3 variant could be involved in a proliferative pathway crucial for glioblastoma cells. Silencing of ErbB3 affects cell viability thus underlining the role of nucleolar ErbB3 as a potential target in glioblastoma.

\section{Nucleolar localization of ErbB3 in a primary culture of glioblastoma affected patients}

The nucleolar localization of ErbB3 was also investigated in glioblastoma primary cells obtained from biopsies of affected patients. Here ErbB3 localizes in the nucleolus as already shown for U-87MG. Treatment with low doses of actinomycin D re-localizes ErbB3 in the nucleoplasm together with C23 (Fig. 6A). The expression of the $50 \mathrm{kDa}$ ErbB3 was also verified by western blot in cellular extracts obtained from glioblastoma primary cell cultures and from U-251MG, A-172 and U-373MG cell lines. All cell lines express the same variant of ErbB3 (Fig. 6B) although at different levels, as shown by the quantification (histogram in Fig. 6B lower panel). Patients biopsies immunostained for ErbB3 show a heterogeneous localization spanning from nucleolus to cytoplasm (Fig. S7). These cells show also the typical reduction of GFAP expression, a hallmark of cancer cells (Fig. 6C) associated to the overall increase in ErbB3 synthesis, as shown from qPCR analysis performed on total RNA extracted from patient biopsies (Fig. 6D).

\section{Discussion}

In several tumors, survival and proliferation are driven by autocrine and paracrine activity of cancer cells. Several reports have identified neuregulin ligands as potential endogenous factor that allows the activation of specific components of EGFR family such as ErbB3 [29-31] and over expression of ErbB3 has been frequently detected in a variety of cancers, including those of the breast, colon, stomach, ovary, pancreas and brain [19, 32-37]. Glioblastoma multiforme is the IV grade glioma that represents the most prevalent malignancy 
A

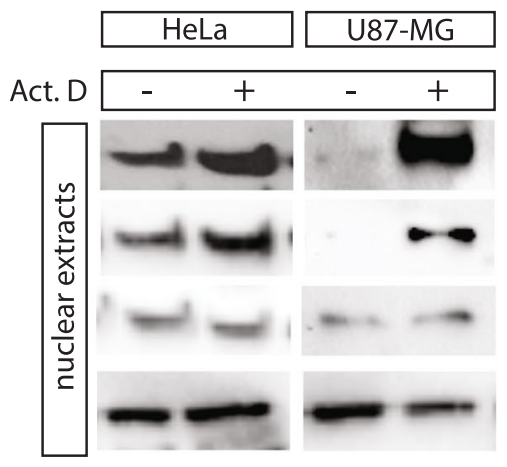

ErbB3, 50 kDa

$\mathrm{C} 23,100 \mathrm{kDa}$

B-Actin

Tubulin

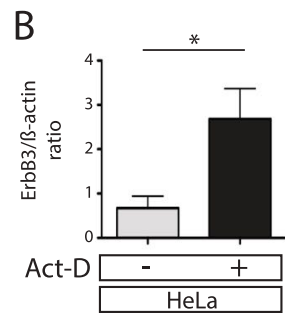

D

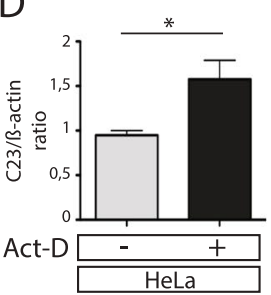

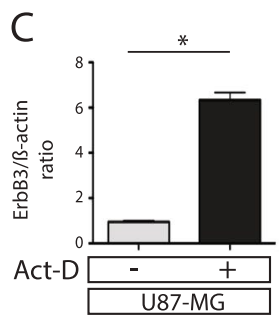

E

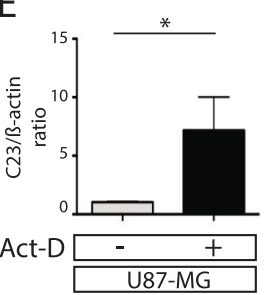

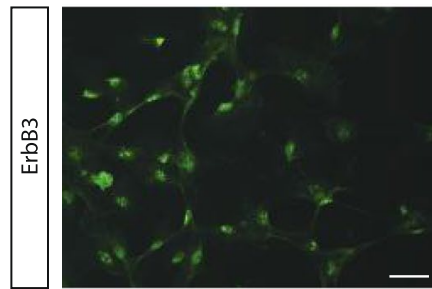

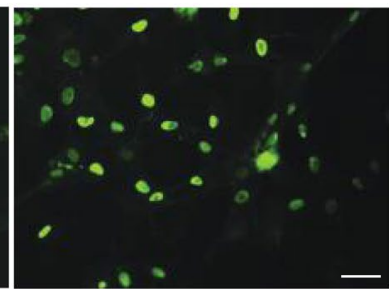

ปิ

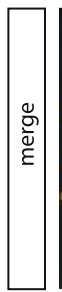

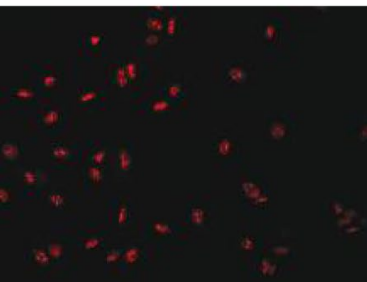
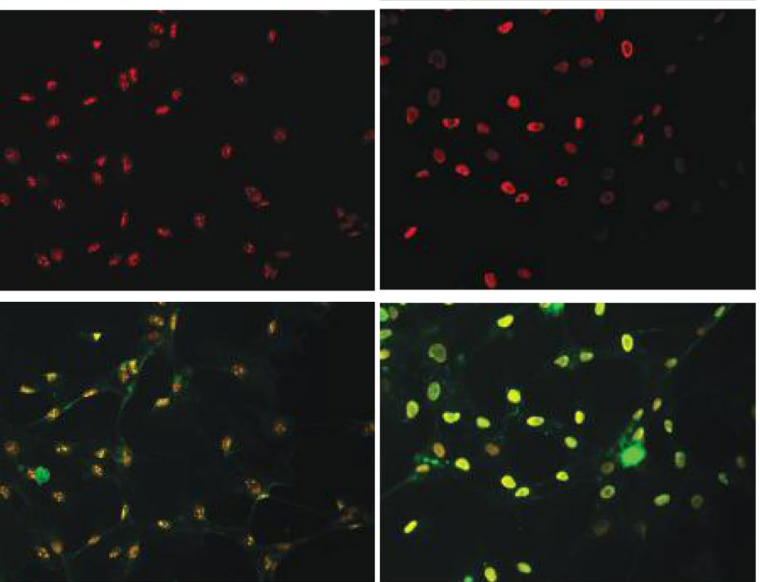

G

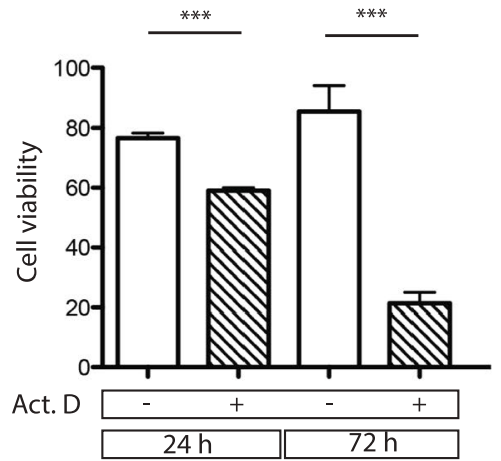

$\mathrm{H}$

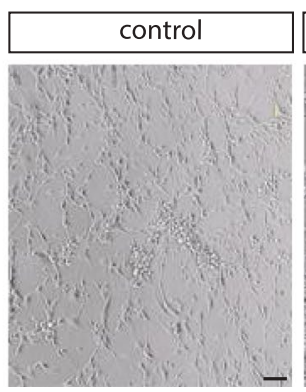

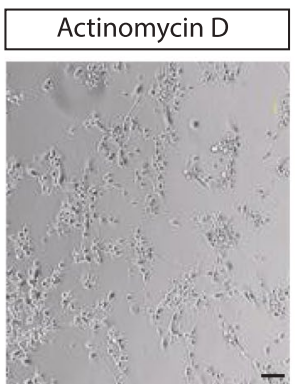

Fig. 4 Nucleolar stress induces nuclear ErbB3 accumulation and affects cell viability. Nuclear extracts obtained from HeLa and U-87MG cells treated with $0,04 \mu \mathrm{g} / \mathrm{ml}$ of actinomycin D were analysed by western blot for the expression of ErbB3 and the nucleolar marker C23 (A). Densitometric quantification of the ErbB3 and C23 signals was performed with the Image J software (B-E). ErbB3 re-localizes to the nucleoplasm upon low Actinomycin treatment in U-87MG cell (F). Scalebar represent $50 \mu \mathrm{m}$. U-87MG cell survival, measured by trypan blue, was strongly affected after actinomycin D treatment (G). Remarkable changes are evident, after $72 \mathrm{~h}$ exposure to actinomycin D and overall cell shape and density $(\mathbf{H})$. Scalebar represent $100 \mu \mathrm{m}$. Data are the average of three independent experiments and significant results are highlighted with asterisks $\left(^{*} p<0.05,{ }^{* * *}\right.$ $p<0.001)$

tumor in the brain. It is characterized by aberrant activation of signaling pathways mediated by receptor tyrosine kinases [38, 39]. Here, ErbB3 overexpression predicts poor prognosis in affected patient and is often associated with resistance to EGFR-target therapy [40]. Several evidence, have shown the involvement of ErbB3 receptors in extra membrane functions in both cancer and normal tissues [20]. In the nucleus a short variant 
A

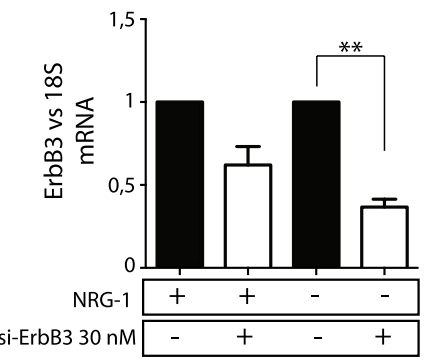

B

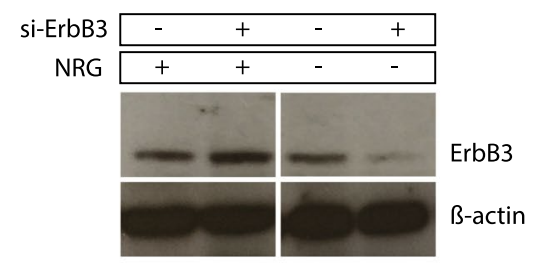

C

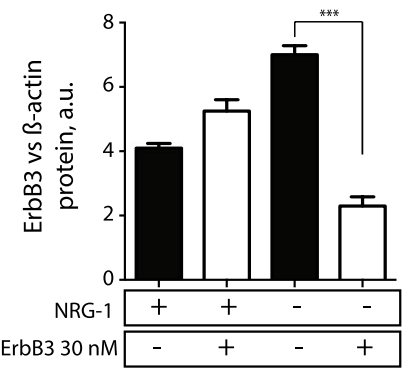

D

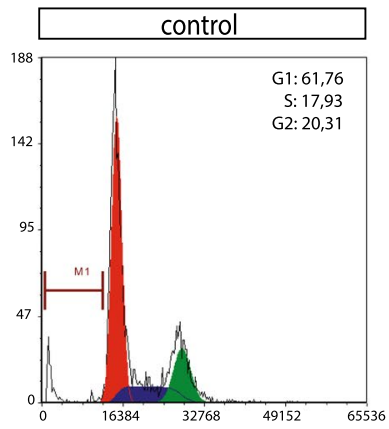

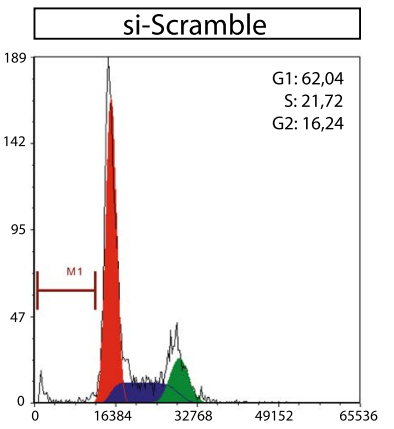

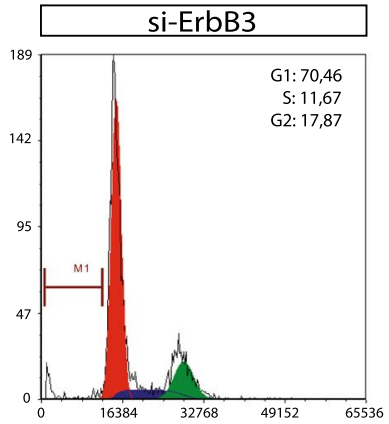

E

$\mathrm{F}$
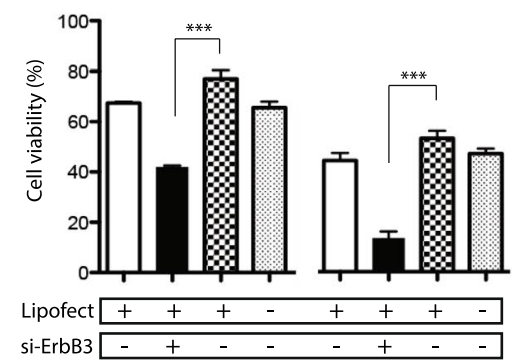

si-Scramble
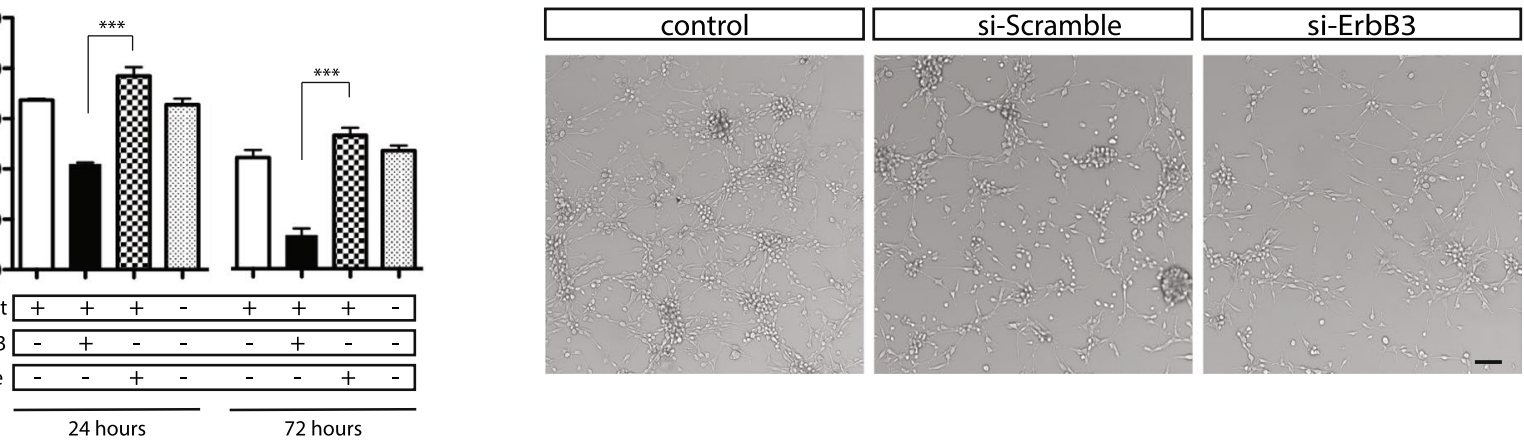

Fig. 5 ErbB3 silencing affects cell cycle progression and cell survival. U-87MG (A-C) cells were transfected with 30 nM of siErbB3 or siScramble as control. The efficiency of ErbB3 silencing was analysed at mRNA level, by qPCR (A) and at protein level by western blot (B). The densitometric quantification of ErbB3 signal, in western blots, was performed by using the Image J software (C). U-87MG cells, transfected with siErbB3 at 30 nM for $24 \mathrm{~h}$, show a decrease percentage of cells in S phase after cytofluorimetry analysis (D). U-87MG cell viability was analysed by trypan blue after 24 and $72 \mathrm{~h}$ of treatment with $30 \mathrm{nM}$ of siErbb3 (E). Representative images of untreated cells and cells treated with $30 \mathrm{nM}$ of siErbB3 or siScramble are shown $(\mathbf{F})$. Scalebar represent $100 \mu \mathrm{m}$. Data are the mean of three independent experiments. Significant results are highlighted with asterisks $(* *$ $p<0.01,{ }^{* * *} p<0.001$ )

of ErbB3 controls the expression of Cyclin-D1 [13], thus strengthening the hypothesis that in the nucleolus it could have the role of neutralize its pro-proliferative effect when required by the cell. In addition, the nucleolus has been shown to represent a special nuclear hub aimed to mask the function of crucial proteins when needed. Following this data, we can easily hypothesize that ErbB3 could shuttle between the nucleolus and cytoplasm following specific "environmental" cues. However, this hypothesis, does not exclude a possible active function of ErbB3 in the nucleolar compartment. Indeed, it could interact with nucleolar components and modulates nucleolar metabolism and ribosome biogenesis. In the present study, we identified for the first time that an already described shorter variant of ErbB3 [21] undergoes relocalization in glioblastoma 

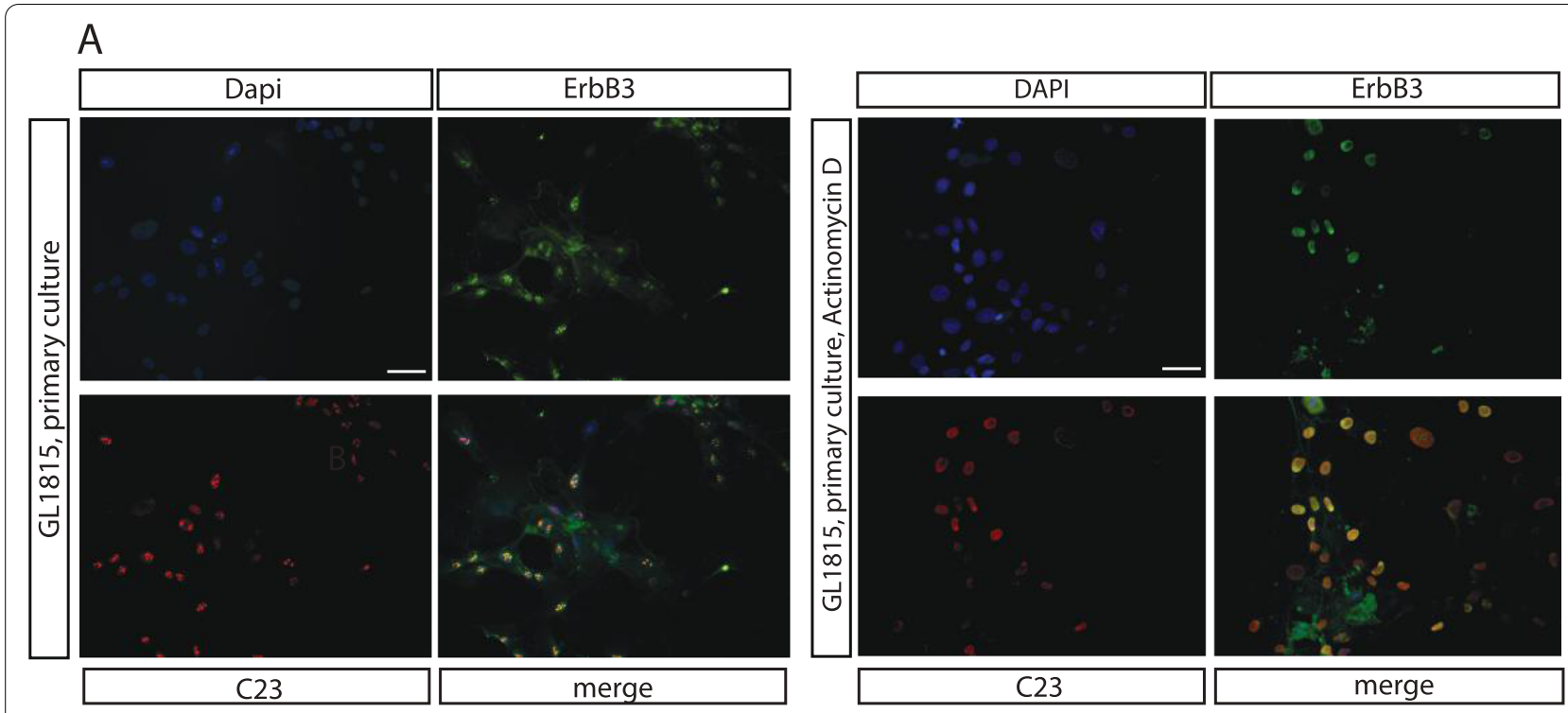

B
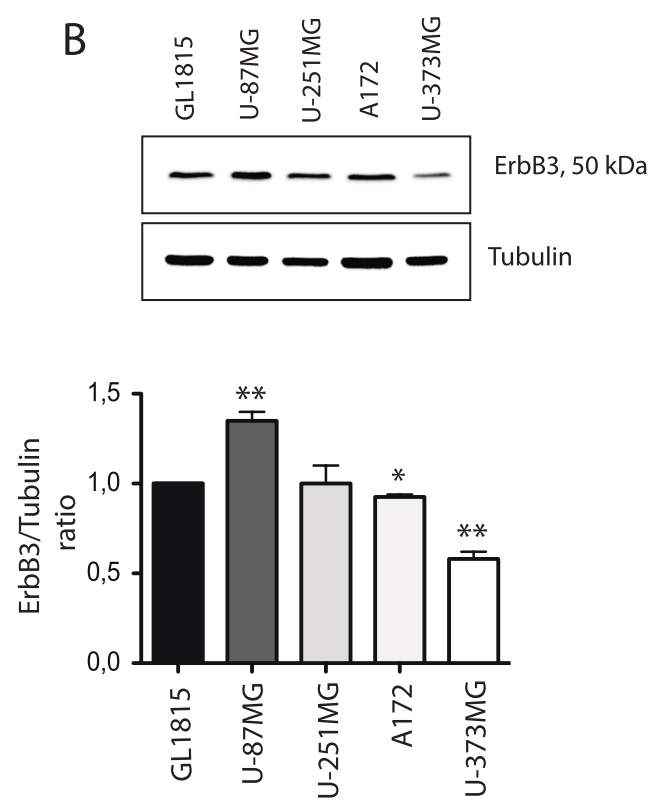

$C$

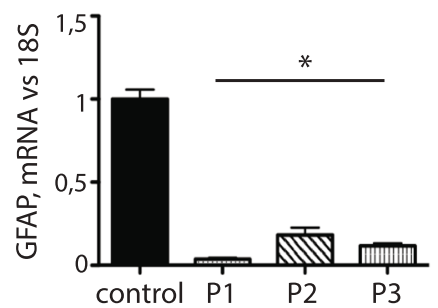

D

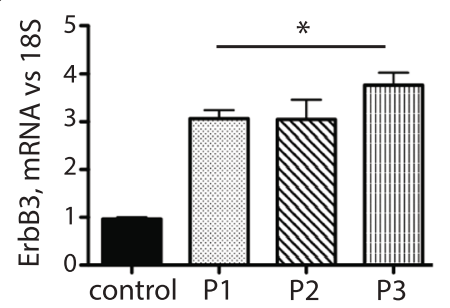

Fig. 6 Nucleolar localization of ErbB3 in primary cells of glioblastoma. ErbB3 localizes in the nucleolus of cells derived from primary glioblastoma culture (left panel) and re-localizes to the nucleoplasm upon low Actinomycin treatment (right panel) (A). Scalebar represent $50 \mu \mathrm{m}$. The specificity of the anti ErbB3 antibody was verified in a primary culture of glioblastoma (GL18-15), in U-87MG, U-251MG, A172 and U-373MG (B). The quantification of the signal is shown in the histogram (B, lower panel). The proteins amount loaded in each lane was $80 \mu \mathrm{g}$. The expression of GAFP $(\mathbf{C})$ and ErbB3 (D) were analyzed by qPCR from mRNA purified from patient biopsies. Data are the average of three independent experiments. Significant results are highlighted with asterisks $(* 0<0.05)$

cancer cells. Here ErbB3 traffic could have two functions: i) to activate the RNA Polymerase I; ii) to confer a gain function to the ErbB3 receptor after the transit through the nucleolus.

We proposed a non-canonical activation pathway for the shorter variant, that does not required the NRG1 binding and ErbB3 heterodimerization. An intriguingly hypothesis is that higher level of NRG1 could activate an alternatively splicing of the full-length receptor. Indeed the silico analysis of the ErbB3 locus predicts 15 different mRNAs, 14 alternatively spliced variants and one unspliced form [21]. Once produced this shorter variant undergoes then nuclear localization driven by an alternative NLS located between the amino acids $1118-1127$ at his C-terminal region [41, 42]. 
Our finding shows a significant reduction of cells in $\mathrm{S}$ phase after ErbB3 silencing, suggesting this approach as a new potential therapeutic treatment alone or in combination with other therapies, to counteract tumor progression in glioblastoma. The most obvious advantage for the ErbB3 translocation into the nucleus is that it can deliver specific signals avoiding the interference of common pathways shared by other membrane receptors. It is known that ErbB3 binds the DNA and interacts with transcription factors involved in cell survival and proliferation [42]. We hypothesized that ErbB3 transit in the nucleolus represents an alternative strategy to influence the RNA polymerase I activity. A possible scenario could be that in conditions of serum starvation the tandem ErbB3/C23 interferes with RNA Polymerase I activity and 47S rRNA synthesis with the reduction of the cell proliferation. When the concentration of NRG1 increases, (overexpressed in high grade glioblastoma), the ErbB3/ C23 could be released from the complex and moves to the cytoplasm, with positive effect on cell proliferation. The binding of actinomycin D interferes with this mechanism and induce nuclear accumulation of ErbB3/ C23 with a reduction of ribosome biogenesis and block of cell proliferation (Fig. 7). Nucleolin has been shown to be overexpressed in glioblastoma where its cytoplasmic localization increases proportionally to the tumor grade [43], thus the interaction between ErbB3 and C23 could have a functional related to tumor progression. This scenario might explain the nucleolar localization of ErbB3 in primary cells of glioblastoma and the partial nucleolar localization observed in patient biopsies. This last data supports our idea that nucleolar localization of ErbB3 may be important also in vivo, although other factors may control or be involved in this process. Regarding a possible therapeutic approach based on a low dose Actinomycin D treatment it is worth mentioning a recent work where the treatment with Actinomycin D at $0.05 \mathrm{mg} / \mathrm{Kg}$ counteracts recurrent glioblastoma [44]. Our work goes in the same direction and our findings support nucleolar ErbB3 as a new player in glioblastoma cancer cells. Thus, drugs involved in nucleolar stress such as Actinomycin D, could be introduced in combination with ErbB3 target therapies as new strategy for targeting these tumors.

\section{Conclusions}

The modulation of the nucleolar ErbB3 could pave the way towards potential anti-cancer backup strategies and could represent a possible novel pharmacological approach to counteract cell proliferation in tumours.

\section{Materials \\ Cell culture}

The MCF-7, HeLa, U-87MG, U-251MG, A172 and U-373MG cell lines, were provided by American Type Collection, Rockville, MD (ATCC). The cell lines were cultivated in DMEM medium or in DMEM-F-12. The mediums in both cases were supplemented with $10 \%$ heat inactivated FBS (Sigma-Aldrich St. Louis, Mo, USA), $2 \mathrm{mM}$ glutamine (GIBCO), $1 \mathrm{mM}$ sodium pyruvate (SIGMA), MEM non-essential amino acids

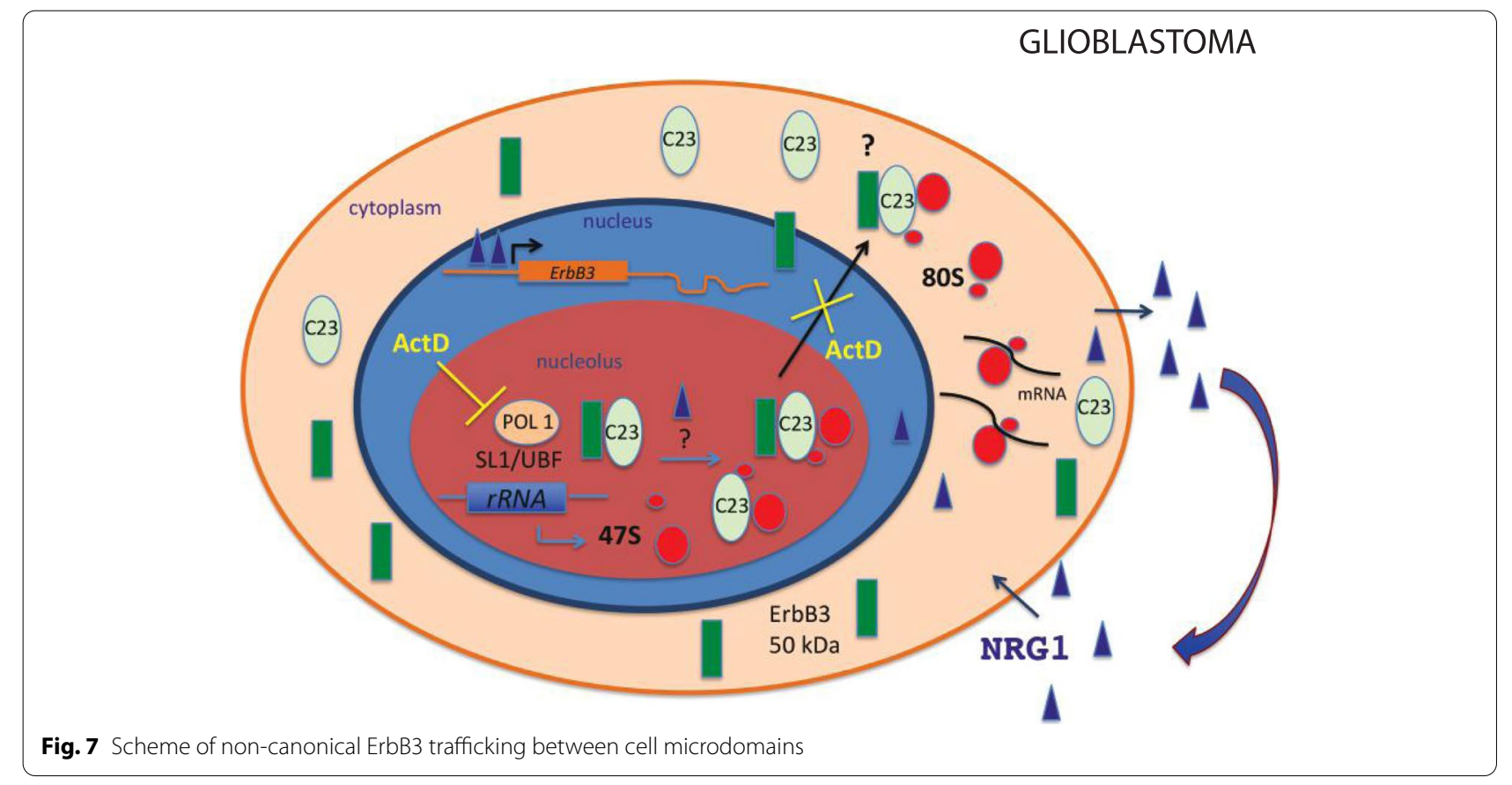


(INVITROGEN), and antibiotics $(100 \mathrm{IU} / \mathrm{ml}$ penicillin, $100 \mathrm{IU} / \mathrm{ml}$ streptomycin) (GIBCO). Cells were maintained in humidified incubators with $5 \% \mathrm{CO}_{2}$ at $37^{\circ} \mathrm{C}$. GL18-15 primary culture was derived from a patient who was diagnosed with glioblastoma (WHO grade IV) and underwent surgical resection. The intraoperatory sample was placed in DMEM/F12 medium supplemented with $10 \% \mathrm{FBS}$ at $4{ }^{\circ} \mathrm{C}$. Then, GBM tissues were minced with scalpel blades and mechanically dissociated with sterile glass pipettes. Before plating, the cell suspension was filtered twice with a $100 \mu \mathrm{m}$ and again with a $70 \mu \mathrm{m}$ cell strainer and centrifuged at $200 \mathrm{x}$ g for $5 \mathrm{~min}$ at room temperature. Medium was half changed every 4 days and the cells were subcultured only when they reached total confluency. The cells were starved in $0.2 \% \mathrm{FBS}$ cultivation medium overnight and stimulated with $4 \mathrm{ng} / \mathrm{ml}$ NRG1 for $15 \mathrm{~min}$ at $37^{\circ} \mathrm{C}$. Nucleolar stress. The cells at $80 \%$ of confluence were incubated with $0,04 \mu \mathrm{g} / \mathrm{ml}$ of Actinomycin D (A9415, Sigma) for $1 \mathrm{~h}$ at $37^{\circ}$. For experiments of viability the treatment was performed for 24 and $72 \mathrm{~h}$ at $37^{\circ} \mathrm{C}$. Cell viability was determined by loading $10 \mu \mathrm{l}$ of the cell suspension into countess cell counting chamber slides that were read by the countess automated cell counter (INVITROGEN, Carlsbad, CA). The cells were diluted 1:1 with trypan blue. Images were acquired with Nikon Eclipse Ni motorized microscope. Three independent experiments were performed in triplicate.

\section{Immunofluorescence analysis}

The immunofluorescence analysis was performed according to Ponti et al. $[4,5]$. Briefly: the cells were cultured in $10 \% \mathrm{FBS}$ or $0.2 \%$ FBS for $18 \mathrm{~h}$ than washed with PBS, fixed for $15 \mathrm{~min}$ with $4 \%$ paraformaldehyde (SIGMAALDRICH-Aldrich St. Louis, Mo, USA). The cells were treated with $0.5 \%$ Triton X-100 for $10 \mathrm{~min}$ and blocked for $40 \mathrm{~min}$ with $0.2 \%$ gelatine. All incubations with primary antibodies were performed in $0.5 \%$ PBS-Triton $\mathrm{X}-100$ overnight at $4{ }^{\circ} \mathrm{C}$. The following primary antibodies were used for immunofluorescence: rabbit polyclonal against anti-ErbB3 (sc-285, SANTA CRUZ BIOTECHNOLOGY, Dallas, Tx, USA), mouse monoclonal antibody anti-fibrillarin (ab4566, Abcam, Cambridge, MA, USA), rabbit polyclonal antibody anti-fibrillarin (PA5-29801, Thermo Fisher Scientific Waltham, Massachusetts, USA) mouse monoclonal antibody anti-B23 (ab10530, Abcam, Cambridge, MA, USA) and mouse monoclonal anti-UBF antibody (sc-13,125, SANTA CRUZ BIOTECHNOLOGY, Dallas, TX, USA). Primary antibodies were diluted at 1:200. Cells were incubated with secondary antibodies, Alexa-Fluor mouse 594 and Alexa Fluor rabbit 488 diluted 1:1000. Immunofluorescence analysis was performed by ViCo (NIKON) or DM4000B (LEICA). For confocal image acquisition, an inverted Zeiss LSM880 with fast airyscan microscope was used. The setup was controlled by ZEN black (software version, Carl Zeiss Microscopy $\mathrm{GmbH}$ ). The nucleolar fluorescence of ErbB3 after NRG1 stimulation was quantified following the instructions reported hereafter https://theolb.readt hedocs.io/en/latest/imaging/measuring-cell-fluorescen ce-using-imagej.html

\section{Immunoblotting and Immunoprecipitation}

Immunoblotting analysis were performed using the mouse monoclonal antibody anti-ErbB3 (RTJ2 THERMO-FISHER), mouse anti-actin (Santa Cruz), anti C23 (sc-8031 Santa Cruz Dallas, TX, USA), anti-tubulin (sc-5274 SANTA CRUZ BIOTECHNOLOGY Dallas, TX, USA). The secondary antibodies used are the anti-mouse and anti-rabbit (GE HEALTHCARE BIO-SCIENCES, Piscataway, NJ, USA). Whole extract. Whole extract were prepared from sub-confluent cultures by resuspending cells in RIPA-Buffer (20 mM Hepes, pH 6.8, $5 \mathrm{mM} \mathrm{KCl}$, $5 \mathrm{mM} \mathrm{MgCl}, 0.5 \% \mathrm{NP}-40,0.1 \%$ sodium deoxycholate, protease inhibitor (SIGMA), $0.1 \mathrm{mM}$ phenylmethylsulfonyl fluoride) after incubation for $30 \mathrm{~min}$ at $4{ }^{\circ} \mathrm{C}$ the samples were centrifuged at $10000 \mathrm{rpm} \times 15 \mathrm{~min} 44^{\circ} \mathrm{C}$. Nuclear extracts: cells at $80 \%$ of confluence were washed twice with PBS, and incubated in NE1 buffer $(10 \mathrm{mM}$ Hepes pH 8.0, $1.5 \mathrm{mM} \mathrm{MgCl}_{2}, 10 \mathrm{mM} \mathrm{KCl}, 1 \mathrm{mM}$ DTT, $0,1 \mathrm{mM}$ PMSF (phenylmethylsulfonyl fluoride) and $1 \mathrm{mM}$ $\mathrm{Na}$-orthovanadate for $15 \mathrm{~min}$ at $4{ }^{\circ} \mathrm{C}$. Homogenization of the cells was performed using a Dounce homogenizer and the lysate was centrifuged at $3000 \mathrm{rpm} \times 5 \mathrm{~min}$ at $4{ }^{\circ} \mathrm{C}$. The nuclear pellet was resuspended in NE2 buffer (20 mM Hepes pH8.0, $1.5 \mathrm{mM} \mathrm{MgCl}_{2}, 25 \%$ glycerol, $420 \mathrm{mM} \mathrm{NaCl}, 0.2 \mathrm{mM}$ EDTA, $1 \mathrm{mM}$ DTT, $1 \mathrm{mM} \mathrm{Na-}$ orthovanadate, $0.1 \mathrm{mM}$ PMSF and incubated for $30 \mathrm{~min}$ at $4^{\circ} \mathrm{C}$. Finally, the supernatant was cleared by centrifuging for $2 \mathrm{~min}$ at $12.000 \mathrm{rpm}$. Nucleolar extracts: the nucleolar extracts were prepared as reported in Ponti et al. [4] and Avitabile et al. [45]. Specific antibodies for each compartments were used: anti Pol I subunit RPA40 (sc101,126, SANTA CRUZ BIOTECHNOLOGY, Dallas, Tx, USA) for the nucleoli; anti GAPDH (ab181602, Abcam, Cambridge, MA, USA) for the cytoplasm and anti lamin B1 (33-2000, Thermo Fisher Scientific Waltham, Massachusetts, USA) for the nuclei. For experiments of immunoprecipitation, an equal amount of precleared HeLa and U-87MG nuclear extracts $(150 \mu \mathrm{g})$ was immunoprecipitated with anti-ErbB3 antibody (RTJ2) or scramble antibodies (IgG $\operatorname{cod}$ n. 5409 Thermo Fisher) for $6 \mathrm{~h}$ at $4^{\circ} \mathrm{C}$ in binding buffer $(50 \mathrm{mM}$ Tris $\mathrm{pH} 7.8$ and $150 \mathrm{mM}$ $\mathrm{NaCl}$ ). The complex was pull down by using magnetic beads (Protein G, MERK, MILLIPORE, Darmstadt, Germany) according to Ponti et al. [4]. After incubation, the beads were washed three times with binding buffer 
and then with $1 \mathrm{x}$ PBS before the incubation at $95^{\circ} \mathrm{C}$ for $10 \mathrm{~min}$ with $50 \mu \mathrm{l}$ of 2 XSDS loading buffer. The immunocomplex eluted was analysed by western blot as previously described by Ponti et al. $[4,5]$. Protein extracts were resolved by $8 \%$ or $10 \%$ SDS-PAGE, blotted by semidry transfer apparatus (BIO-RAD) on $0.45 \mu \mathrm{M}$ PVDF (AMERSHAM, Buckinghamshire, UK). The incubation with primary antibodies was performed overnight in $5 \%$ dry milk (CELL SIGNALING) at $4{ }^{\circ} \mathrm{C}$ (dilution 1:1000) followed by the incubation with secondary antibodies (AMERSHAM, Buckinghamshire, UK) (dilution 1:10000). The protein detection was performed by ECL reaction (AMERSHAM Buckinghamshire, UK) according to the manufacturer's instructions. The images were acquired by ChemiDoc XRS + with Image Lab Software (BIORAD) or revealed by Kodak film (AMERSHAM Hyperfilm ECL). All experiments have been done in triplicate. The Band quantification was performed with the ImageJ software and the data shown in the histograms represent the average of at least three independent experiments.

\section{qRT-PCR}

Total RNA was extracted from cell lines by using Qiazol reagent (BIORAD). For cDNA preparation $1 \mu \mathrm{g}$ of RNA was used for reverse transcription by SensiFast cDNA (BIOLINE) kit according to the manufacturer's recommendations. The tissue of patients stored at $-80^{\circ} \mathrm{C}$ in OCT (Optimal cutting temperature compound) and used for total RNA extraction by using the Qiagen FFPE plus mini kit (QIAGEN). The samples were processed by electrical homogenizer (IKA T-10 basic). cDNA preparation was performed by using the High capacity cDNA reverse transcription kit (APPLIED BIOSYSTEM). The quantification of total RNA was performed, by using Nanodrop one (Thermo Fischer). For silencing the ErbB3 predesigned siRNA (INVITROGEN, Grand Island, NY USA cod. AM16708) or scrambled sequence RNA oligonucleotide, (INVITROGENE, Grand Island, NY USA cod. siRNA $4,390,846)$ were transiently transfected at $30 \mathrm{nM}$ using Lipofectamine 2000 agent (INVITROGENE) according to the manufacturer's instructions. Quantitative RT-PCR was performed using Fast SYBR Green Master mix and the StepOnePlus real-time PCR system (APPLIED BIOSYSTEMS). Each experiment was performed in triplicate and is expressed as mean 6 SEM. Experiments were independently repeated three times. Gene expression levels were quantified from real-time PCR data by the comparative threshold cycle (CT) method using $18 \mathrm{~S}$ as an internal control gene according to Ponti et al. [4, 5]. All the experiments have been repeated at least three times.
47S: FW 5'-TGTCAGGCGTTCTCGTCTC-3' and REV 5'-GAGAGCACGACGTCACCAC-3';

18S: FW $5^{\prime}$-GCAATTATTCCCCATGAACG-3' and REV 5'-GGGACTTAATCAACGCAAGC-3'; ErbB3: FW 5'-CAGGTTCAGGTGGCAGATTT- ${ }^{\prime}$ and REV $5^{\prime}$-TCT CAAGGGCCATCCACTTA-3'; GFAP: FW 5'-AGCCAC ATCGCTCAGA CAC-3' REV 5'-GCCCAATACGAC CAAATCC- $3^{\prime}$.

\section{Cell cycle}

For cell cycle analysis, $1 \times 10^{6}$ cells were fixed in $70 \%$ ethanol for $24 \mathrm{~h}$, incubated with $50 \mu \mathrm{g} / \mathrm{ml}$ propidium iodide (PI, SIGMA-ALDRICH) and 50 units/ml DNase-free RNase A (SIGMA-ALDRICHigma-Aldrich) and analysed after $3 \mathrm{~h}$ using an Epics XL Cytometer (BECKMAN COULTER, Brea, CA). Each experiment was performed independently three times.

\section{Immunohistochemistry}

The immunohistochemistry was conducted as previously described by Rosa et al. [46] with some modifications. In Brief, paraffin-embedded tissues of 2 GBM patients were deparaffinized in xylene, rehydrated in descending graded alcohols, incubated for $15 \mathrm{~min}$ in $3 \% \mathrm{H} 2 \mathrm{O} 2$ in methanol to block the activity of endogenous peroxidase activity, and then subjected to heat-induced antigen retrieval for $20 \mathrm{~min}$ in sodium citrate buffer $(10 \mathrm{mM}$ trisodium citrate dihydrate, $0.05 \%$ Tween 20 , pH6.0). After a blocking step with normal horse serum for $1 \mathrm{~h}$, sections were incubated overnight with mouse anti-ErbB3 (sc17, dilution $1: 200$ ) at $4^{\circ} \mathrm{C}$, washed three times with PBS, incubated for $1 \mathrm{~h}$ at room temperature with biotinylated universal secondary antibody (Vectastain Universal Elite $\mathrm{ABC}$ kit, Vector Laboratories, Burlingame, $\mathrm{CA}$ ), washed three times with PBS and then incubated with the avidin-biotin-peroxidase complex according to the manufacturer's instructions. Slides were successively stained with 3-3-diaminobenzidine (ImmPACT DAB peroxidase substrate, Vector Laboratories, Burlingame, CA) to visualize the reaction product, and were counterstained with hematoxylin to visualize nuclei. A Nikon Eclipse $\mathrm{Ni}$ motorized microscope system at 20x magnification was used to acquire images. This study was carried out according to the principles of the Helsinki Declaration and the protocols approved by the ethics committee.

\section{Statistical analysis}

Each experiment was repeated at least three times. Statistical procedures were performed using Graphpad Prism 5 software. Statistical comparisons were performed using Student's $t$-test and a one-way analysis of variance (ANOVA). A $P$-value of 0.05 or lower considered to be statistically significant. 


\section{Abbreviations}

ErbB3: Receptor tyrosine-protein kinase erb3; UBF: Upstream binding factor; siErbB3: Silencing ErbB3; EGFR: Epidermal growth factor receptor; ARF: Alternate reading frame protein; EGR1: Early growth response 1; ActD: Actinomycin D; GFAP: Glial fibrillary acidic protein; ErbB3: v-erb-b erythroblastic leukemia viral oncogene homolog 3 .

\section{Supplementary Information}

The online version contains supplementary material available at https://doi. org/10.1186/s12860-022-00411-y.

Additional file 1: Supplementary Figure 1. (A) ErbB3 localizes in the nucleolus of HeLa and MCF-7 cells. Immunofluorescence analysis for ErbB3 (green) and Fibrillarin (red) after 24h of serum starvation (0.2\% FBS). (B). Confocal magnifications and relative lateral sections are shown HeLa cells. (C) ErbB3 localization in MCF-7. The staining was performed using rabbit polyclonal anti-ErbB3 C17 (green), anti Pol I subunit RPA40 (red). The colocalization is shown in yellow. Scalebar represent $10 \mu \mathrm{m}$ in A and $25 \mu \mathrm{m}$ in $\mathrm{C}$.

Additional file 2: Supplementary Figure 2. (A) Immunofluorescence of U-87MG without anti-ErbB3 primary antibody. Cells were treated only with the secondary antibody Alexa Flour 488 (secondary antibody in green and dapi in blue). No nucleolar specific signal was detected. (B) Immunofluorescence of U-87MG without permeabilization. Cells were treated with primary (anti-ErbB3) and secondary (Alexa Fluor 488) without the permeabilization step. (ErbB3 in green and dapi in blue). No nucleolar specific signal was detected.

Additional file 3: Supplementary Figure S3. ErbB3 localizes in the nucleolus of U-87MG probed with an anti ErbB3 RTJ2 monoclonal antibody after $24 \mathrm{~h}$ of serum starvation $(0.2 \% \mathrm{FBS})$. ErbB3 is shown in green and Fibrillarin in red. Scalebar represent $5 \mu \mathrm{m}$.

Additional file 4: Supplementary Figure 4. The $50 \mathrm{kDa}$ variant of ErbB3 is detected in MCF-7 cells. (A) SDS-page of whole cells lysate from U-87MG and MCF-7. Approximatively $40 \mu \mathrm{g}$ were loaded on each lane. (B) Quantification of ErbB3 expression. Data is the mean of three independent experiments. $\left({ }^{* *} p<0.01\right)$

Additional file 5: Supplementary Figure S5. HeLa cells were subjected to cell fractionation after $15 \mathrm{~min}$ of Neuregulin 1 stimulation and analysed by western blot.

Additional file 6: Supplementary Figure 6. Difference in medium $\mathrm{pH}$ of U-87MG after 72h exposure to actinomycin D.

Additional file 7: Supplementary Figure 7. Immunohistochemistry of glioblastoma patient biopsies. ErbB3 is stained in brown and the nuclei are in blue.

Additional file 8:. Supplementary information.

\section{Acknowledgements}

The authors gratefully acknowledge Nikky Corthout from the VIB BIO Imaging Core for her support and assistance with confocal images acquisition and the Prof. Gabriele Bergers that provided the U-87MG used for the revision of the paper.

\section{Authors' contributions}

Conceived and designed the experiments: DP, MT, GCB. Performed the experiments: DP, MT, PR, RT, CT, FF. Analyzed the data: DP, MT, AC, GCB, FF. Performed statistical analysis: MT DB. Wrote the paper: DP and GCB. All the authors have read and approved the final manuscript.

\section{Funding}

This work was supported by University of Rome La Sapienza, Ateneo (2015-2017), by MIUR to DP (University La Sapienza, Project n. C26A14WBCS, C26A15HF29, RP1 16155037D13E1 and MIUR 2017 C.U.P. B25D17000260005), and MIUR-PRIN 2017T9JNLT 004 to GCB.
Availability of data and materials

All data generated or analysed during this study are included in this published article.

\section{Declarations}

Ethics approval and consent to participate

A signed written informed consent was provided by patients. The study was approved by the Ethical Committee of "Sapienza" University of Rome and carried out according to the principles of the Helsinki Declaration. The study is considered to meet the ethical requirements.

\section{Consent for publication}

Not applicable.

\section{Competing interests}

The authors have declared that no competing interests exist.

\section{Author details}

${ }^{1}$ Department of Medical-Surgical Sciences and Biotechnologies, University of Rome La Sapienza, Corso della Repubblica 79, 04100 Latina, Italy. ${ }^{2}$ Institute of Genetics and Biophysics "Adriano Buzzati Traverso" CNR, 80131 Naples, Italy. ${ }^{3}$ Fondazione Santa Lucia IRCCS, 00143 Rome, Italy. ${ }^{4}$ Department of Systems Medicine, University of Tor Vergata, 00133 Rome, Italy. ${ }^{5}$ Istituto Chirurgico Ortopedico Traumatologico, 04100 Latina, Italy. ${ }^{6}$ Laboratory of Tumor Inflammation and Angiogenesis, Center for Cancer Biology (CCB), VIB, Leuven, Belgium. ${ }^{7}$ Laboratory of Tumor Inflammation and Angiogenesis, and Department of Oncology, KU Leuven, Leuven, Belgium. ${ }^{8}$ Department of Anatomical, Histological, Forensic and Orthopaedic Sciences, Sapienza University of Rome, 00185 Rome, Italy.

Received: 13 July 2021 Accepted: 14 February 2022

Published online: 07 March 2022

\section{References}

1. Bersaglieri C, Santoro R. Genome organization around the nucleolus. Cells. 2019;8:579.

2. Boisvert FM, Van Koningsbruggen S, Navascues J, Lamond AL. The multifunctional nucleolus. Nat Rev Mol. 2007;8:574-85.

3. Chen L, Chen J. MDM2-ARF complex regulates p53 sumoylation. Oncogene. 2003;22:5348-57.

4. Ponti D, Bellenchi GC, Puca R, Bastianelli D, Maroder M, Ragona G, et al. The transcription factor EGR1 localizes to the nucleolus and is linked to suppression of ribosomal precursor synthesis. PLoS One. 2014. https:// doi.org/10.1371/journal.pone.0096037.

5. Ponti D, Bastianelli D, Rosa P, Pacini L, Ibrahim M, Rendina EA, et al. The expression of B23 and EGR1 proteins is functionally linked in tumor cells under stress conditions. BMC Cell Biol. 2015;16:27.

6. Stefanovsky V, Langlois F, Gagnon-Kugler T, Rothblum LI, Moss T. Growth factor signaling regulates elongation of RNA polymerase I transcription in mammals via UBF phosphorylation and R-chromatin remodeling. Mol Cell. 2006;21:629-39.

7. Scherl A, Couté Y, Déon C, Callé A, Kindbeiter K, Sanchez JC, et al. Functional proteomic analysis of human nucleolus. Mol Biol Cell. 2002:3:4100-41092.

8. Ruggero D, Pandolfi PP. Does the ribosome translate cancer? Nat Rev Cancer. 2003;3:179-92.

9. Weeks SE, Metge BJ. The nucleolus: a central response hub for the stressors that drive cancer progression. Cell Mol Life Sci. 2019;76:4511-24.

10. Cerqueira AV, Lemos B. Ribosomal DNA and nucleolus as keystones of nucleolar architecture organization and function. Trends Genet. 2019:10:P710-23.

11. Andersen JS, Lyon CE, Fox AKL, Leung AKL, Lam YW, Steen H, et al. Directed proteomic analysis of human nucleolus. Curr Biol. 2002;12:1-11.

12. Ueshima S, Nagata K, Okuwaki M. Internal associations of the acidic region of upstream binding factor control its nucleolar localization. Mol Cell Biol. 2017;37:e00218-17. 
13. Andrique L, Fauvin D, Maassarani M, Colasson H, Vannier B, Séité P. ErbB3 $80 \mathrm{kDa}$, a nuclear variant of the ErbB3 receptor, binds to the Cyclin D1 promoter to activate cell proliferation but is negatively controlled by p14ARF. Cell Signal. 2012;24:1074-85.

14. Kruspig B, Monteverde T, Neidler S, Hock A, Kerr E, Nixon C, et al. The Erbb network facilitates KRAS-driven lung tumorigeneis. Sci Transl Med. 2018. https://doi.org/10.1126/scitranslmed.aao2565.

15. Wang Z. ErbB receptors and cancer. In: Wang Z, editor. ErbB receptor signaling. Methods in molecular biology, vol 1652. New York: Humana Press; 2017. https://doi.org/10.1007/978-1-4939-7219-7_1.

16. Wang YN, Yamaguchi H, Hsu JM, Hung MC. Nuclear trafficking of the epidermal growth factor receptor family membrane proteins. Oncogene. 2010;29:3997-4006

17. Giri DK, Ali-Seyed M, Li LY, Lee DF, Ling P, Bartholomeusz G, et al. Endosomal transport of ErbB-2: mechanism for nuclear entry of the cell surface receptor. Mol Cell Biol. 2005;25:11005-18.

18. Ni CY, Murphy MP, Golde TE, Carpenter G. C-Secretase cleavage and nuclear localization of ErbB-4 receptor tyrosine kinase. Science. 2001;294:2179-81.

19. Sihanandam G, Anderson LM. The ERBB3 receptor in cancer and cancer gene therapy. Cancer Gene Ther. 2008;15:413-48.

20. Thompson M, Lauderdale S, Webster MJ, Chong VZ, McClintock B, Saunders R, et al. Widespread expression VZ of ErbB2, ErbB3 and ErbB4 in non-human primate. Brain Brain Res. 2007;1139:95-109.

21. Adilakshmi T, Ness-Myers J, Madris-Aliste C, Fiser A, Tapinos N. A nuclear variant of ErbB3 receptor tyrosine kinase regulates Ezrin distribution and Schwann cell myelination. J Neurosci. 2011:31:5106-19.

22. Kancha RK, Von Buboff N, Duyster J. Asymmetric kinase dimer formation is crucial for the activation of oncogenic EGFRvIll but not for ERBB3 phosphorylation. Cell Commun Signal. 2013;11:39.

23. Chen B, Mao R, Wang H, She JX. Cell line and drug-dependent effect of ERBB3 on cancer cell proliferation, chemosensitivity, and multidrug actions. Int J High Throughput Screen. 2010;1:49-55.

24. Frogne T, Benjaminsen RV, Sonne-Hansen K, Sorensen BS, Nexo BS, Laenkholm AV, et al. Activation of ErbB3, EGFR and Erk is essential for growth of human breast cancer cell lines with acquired resistance to fulvestrant 2009. Breast Cancer Res Treat. 2009;11:263-75.

25. Aguilar Z, Akita RW, Finn RS, Ramos BL, Pegram MD, Kabbinavar FF, et al. Biologic effects of heregulin/neu differentiation factor on normal and malignant human breast and ovarian epithelial cells. Oncogene. 1999;18:6050-62.

26. Wolfson E, Solomon S, Schmukler E, Goldshmit Y, Pinkas-Kramarski R. Nucleolin and ErbB2 inhibition reduces Tumorigenicity of ErbB2-positive breast cancer. Cell Death Dis. 2018;9:47.

27. Mi Y, Thomas SD, Xu X, Casson LK, Miller DM, Bates PJ. Apoptosis in leukemia cells is accompanied by alterations in the levels and localization of nucleolin. J Biol Chem. 2003;278:8572-9.

28. Ma H, Pederson T. The nucleolus stress response is coupled to an ATRChk1-mediated G2 arrest. Mol Biol Cell. 2013;24:1334-42.

29. Auf G, Jabouille A, Delugin M, Guérit S, Pineau R, North S, et al. High Epiregulin expression in human U87 Glioma cells relies on IRE1 a and promotes Autocrine growth through EGF receptor. BMC Cancer. 2013;13:597.

30. Ritch PS, Carroll SL, Sontheimer H. Neuregulin-1 enhances survival of human Astrocytic Glioma cells. Glia. 2005;51:217-28.

31. Wilson TR, Lee DY, Berry L, Shames DS, Settleman J. Neuregulin-1-mediated Autocrine signaling underlies sensitivity to HER2 kinase inhibitors in a subset of human cancers cancer. Cell. 2011;20:158-72.

32. Clark PA, Lida M, Treisman DM, Kalluri H, Ezhilan S, Zorniak M, et al. Activation of multiple ERBB family receptors mediates Glioblastoma cancer stem-like cell resistance to EGFR-targeted inhibition. Neoplasia. 2012;14:420-8.

33. Naidu R, Yadav M, Nair S, Kutty MK. Expression of C-ERBB3 protein in primary breast carcinomas. Br J Cancer. 1998;78:1385-90.

34. Ciardiello F, Kim N, Saeki T, Dono R, Persico MG, Plowman GD, et al. Differential expression of epidermal growth factor-related proteins in human colorectal tumors. Proc Natl Acad Sci U S A. 1991:88:7792-6.

35. Hayashi M, Inokuchi M, Takagi Y, Yamada H, Kojima K, Kumagai J, et al. High expression of HER3 is associated with a decreased survival in gastric cancer. Clin Cancer Res. 2008;14:7843-9.
36. Lin SH, Cheng CJ, Lee YC, Ye X, Tsai WW, Kim J, et al. A 45-kDa ErbB3 secreted by prostate cancer cells promotes bone formation. Oncogene. 2008:27:5195-203.

37. Rampogu S, Son M, Baek A, Park C, Rana RM, Zeb A, et al. Targeting natural compounds against HER2 kinase domain as potential anticancer drugs. Applying Pharmacophore based molecular Modelling approaches. Comput Biol Chem. 2018;74:327-38.

38. Cancer Genome Atlas Research Network. Comprehensive genomic characterization defines human glioblastoma genes and core pathways. Nature. 2008;455:061-1068.

39. Verhaak RG, Hoadley KA, Purdom E, Wang V, Qi Y, Wilkerson MD, et al. Cancer genome atlas research network. Integrated genomic analysis identifies clinically relevant subtypes of glioblastoma characterized by abnormalities in PDGFRA, IDH1, EGFR, and NF1. Cancer Cell. 2010;17:98-110.

40. Song K, Yuan Y, Lin Y, Wang YX, Zhou J, Gai QJ, et al. ERBB3, IGF1R, and TGFBR2 expression correlate with PDGFR expression in Glioblastoma and participate in PDGFR inhibitor resistance of Glioblastoma. Cells Am J Cancer Res. 2018;8:792-809.

41. Hsu S-C, Hung M-C. Characterization of a novel tripartite nuclear localization sequence in the EGFR family. J Biol Chem. 2007;82:10432-40.

42. Reif R, Adawy A, Vartak N, Schröder J, Günther G, Ghallab A, et al. Activated ErbB3 translocates to the nucleus via clathrin-independent endocytosis which is associated with proliferating cells. J Biol Chem. 2016:291:3837-47.

43. Balça-Silva J, Do Carmo A, Tão H, Rebelo O, Barbosa M, Moura-Neto V et al. Nucleolin is expressed in patient-derived samples and glioblastoma cells, enabling improved intracellular drug delivery and cytotoxicity. Exp Cell Res. 2018;370:68-77.

44. Taylor JT, Ellison S, Pandele A, Wood S, Nathan E, Forte G, et al. Actinomycin D Downregulates Sox2 and improves survival in preclinical models of recurrent Glioblastoma. Neuro-Oncology. 2020. https://doi.org/10.1093/ neuonc/noaa051.

45. Avitabile D, Genovese L, Ponti D, Ranieri D, Raffa S, Calogero A, et al. Nucleolar localization and circadian regulation of Per2S, a novel splicing variant of the period 2 gene. Cell Mol Life Sci. 2014;71:2547-59.

46. Rosa P, Zerbinati C, Crestini A, Canudas AM, Ragona G, Confaloni A, et al. Heme Oxygenase-1 and brain Oxysterols metabolism are linked to Egr-1 expression in aged mice cortex, but not in hippocampus. Front Aging Neurosci. 2018;10:363.

\section{Publisher's Note}

Springer Nature remains neutral with regard to jurisdictional claims in published maps and institutional affiliations.

Ready to submit your research? Choose BMC and benefit from

- fast, convenient online submission

- thorough peer review by experienced researchers in your field

- rapid publication on acceptance

- support for research data, including large and complex data types

- gold Open Access which fosters wider collaboration and increased citations

- maximum visibility for your research: over 100M website views per year

At BMC, research is always in progress.

Learn more biomedcentral.com/submissions 